\title{
Influence of selected phases of the menstrual cycle on performance in Special judo fitness test and Wingate test
}

\author{
Miloš Štefanovský1,*, Alexandra Péterová ${ }^{1}$, Marián Vanderka ${ }^{1}$, and Lukáš Lengvarský \\ ${ }^{1}$ Faculty of Physical Education and Sport, Comenius University, Bratislava, Slovakia; and ${ }^{2}$ National Sport Center, Bratislava, Slovakia
}

Copyright: (C) 2016 M. Štefanovský et al. This is an open access article licensed under the Creative Commons Attribution License (http://creativecommons.org/licenses/by/4.0/).

Background: Several scientific papers in recent years dealt with the menstrual cycle and its impact on female sport performance. No differences have been found in aerobic performance, but the results of the studies dealing with the influence of the menstrual cycle on anaerobic performance are often controversial. Objective: The aim of this study was to verify the effect of selected phases of the menstrual cycle on anaerobic performance of judokas in the Wingate test and Special judo fitness test. Methods: The research sample was composed of 8 young female judokas (age $18.14 \pm 3.44$ years; body weight $63.86 \pm 10.42 \mathrm{~kg}$; height $165.43 \pm 5.09 \mathrm{~cm}$; judo practice $11.14 \pm 3.13$ years). The observed parameters in the Wingate test were as follows: a) anaerobic peak power; b) anaerobic capacity; c) fatigue index; d) blood lactate in the $5^{\text {th }}$ minute after completing the test. In Special judo fitness test (SJFT) we measured the following parameters: a) number of throws in the first period; b) second period; c) third period; d) total number of throws; e) SJFT index. For the processing and evaluation of obtained data, we used the non-parametric Wilcoxon $t$-test and effect sizes are described by Cohen's $d$. Results: No significant changes have been observed in any of those parameters in the Wingate test and Special judo fitness test due to changes of menstrual phases, except of number of throws in the first 15-s period of the Special judo fitness test with better performance in luteal phase $(p=.03$; Cohen's $d=1.149$ ). Conclusion: Better anaerobic performance in luteal phase could be a result of potential larger phosphocreatine and adenosine triphosphate stores, which can have a positive effect on high intensity specific judo performance.

Keywords: menstruation, follicular and luteal phase, Wingate test, Special judo fitness test, performance

\section{Introduction}

Judo is characterized as an Olympic combat sport which requires a high level of technical skills, explosive power, anaerobic endurance and capacity (Callister et al., 1991; Pulkkinen, 2001; Štefanovský, 2008; Takahashi, 1992; Thomas, Cox, LeGal, Verde, \& Smith, 1989). A judo match has an intermittent character, with a section of load between 10-30 seconds and with breaks 5-10 seconds. Short breaks between high intensity effort during a match are insufficient for the recovery of phosphocreatine (PC) stores and lactate accumulates in the muscles (McMahon \& Jenkins, 2002). The rate of anaerobic glycolysis is particularly significant in the first minutes of a judo match, while aerobic glycolysis increases towards the end of the match, respectively

\footnotetext{
* Address for correspondence: Miloš Štefanovský, Department of Gymnastics, Faculty of Physical Education and Sport, Comenius University, Nábr. arm. gen. L. Svobodu 9, 81469 Bratislava, Slovakia. E-mail: milos.stefanovsky@uniba.sk
}

in its overtime (Glaister, 2005; Muramatsu, Horiyasu, \& Sato, 1994; Tabata, Irisawa, \& Kouzaki, 1997). The rate of the lactate utilization can be influenced by the level of $\mathrm{VO}_{2}$ max. Higher $\mathrm{VO}_{2} \max$ can be a great advantage, especially during the one competitive day, when the successful judoka has to complete 4 up to 7 matches and the break between them is getting shorter, with the exception of finals (Štefanovský et al., 2014). If judokas have to make quick attacks at the end of the match, the organism reacts and tries not to use energy only from anaerobic glycolysis, but more and faster uses PC stores. This was experimentally confirmed for example by authors Bangsbo and Reilly (1998) in the test of $10 \times 6$ seconds sprints.

The competition rules, techniques to overcome the opponent and training methods as well are in judo identical for both genders, but in the training process, it is necessary to respect certain anatomical, biological and psychological differences. When creating a judo training programme for women, the menstrual cycle (MC) should be considered as one of the important factors. 
The menstrual cycle is the regular natural change that occurs in the female reproductive system like the uterus and ovaries that make pregnancy possible. The menstrual cycle typically occurs on a monthly basis between puberty and menopause. A cycle duration is between 21-35 days. Ganong (2005) refers that average length of menstrual cycle is usually 28 days. The menstrual cycle is governed by hormonal changes. These changes can be altered by using hormonal birth control to prevent pregnancy. Each cycle can be divided into three phases based on events in the ovary (ovarian cycle) or in the uterus (uterine cycle). The ovarian cycle consists of the follicular phase, ovulation, and luteal phase whereas the uterine cycle is divided into menstruation, proliferative phase, and secretory phase (Klump et al., 2013; Sherwood, 2013; Silverthorn, 2013).

The follicular phase (FP) is the first part of the ovarian cycle. During this phase, the ovarian follicles mature and prepare to release an egg. The latter part of this phase overlaps with the proliferative phase of the uterine cycle. Through the influence of a rise in follicle stimulating hormone (FSH) during the first days of the cycle, a few ovarian follicles are stimulated. These follicles, which were present at birth and have been developing for the better part of a year in a process known as folliculogenesis, compete with each other for dominance. Under the influence of several hormones, all but one of these follicles will stop growing, while one dominant follicle in the ovary will continue to maturity (Losos, Raven, Johnson, \& Singer, 2002; Silverthorn, 2013). Ovulation is the second phase of the ovarian cycle in which a mature egg is released from the ovarian follicles into the oviduct. During the follicular phase, estradiol suppresses production of luteinizing hormone (LH) from the anterior pituitary gland. When the egg has nearly matured, levels of estradiol reach a threshold above which this effect is reversed and estrogen stimulates the production of a large amount of LH. This process, known as the LH surge, starts around day 12 of the average cycle and may last 48 hours. The luteal phase (LP) is the final phase of the ovarian cycle and it corresponds to the secretory phase of the uterine cycle. During the luteal phase, the pituitary hormones FSH and LH cause the remaining parts of the dominant follicle to transform into the corpus luteum, which produces progesterone. The increased progesterone in the adrenals starts to induce the production of estrogen. The hormones produced by the corpus luteum also suppress production of the FSH and LH that the corpus luteum needs to maintain itself. Consequently, the level of FSH and LH fall quickly over time, and the corpus luteum subsequently atrophies. Falling levels of progesterone trigger menstruation and the beginning of the next cycle. From the time of ovulation until progesterone withdrawal has caused menstruation to begin, the process typically takes about two weeks, with 14 days considered normal. For an individual woman, the follicular phase often varies in length from cycle to cycle; by contrast, the length of her luteal phase will be fairly consistent from cycle to cycle (Losos et al., 2002).

Several scientific papers in recent years have dealt with the menstrual cycle and its impact on female sport performance. No differences have been found in the aerobic performance $\left(\mathrm{VO}_{2} \max \right)$ during the phases of the menstrual cycle, regardless of whether or not the subject is taking oral contraceptives (Burrows \& Bird, 2005; Lamina, Hanif, \& Muhammed, 2011; Máček \& Radvanský, 2011; Oosthuyse, Bosch, \& Jackson, 2005; Vaiksaar et al., 2011).

On the other hand, the results of the studies dealing with the influence of the menstrual cycle on anaerobic performance are often controversial. For example, Middelton and Wenger (2006) found significantly higher anaerobic capacity in the luteal phase. Masterson (1999) discovered better anaerobic capacity, anaerobic power and lower fatigue index in the luteal phase as well. Wearing, Yuhosz, Campbell, and Love (1972) confirmed that weakest performance in the high jump test was recorded during the period of menstruation. On the other hand, significantly higher performance in the follicular phase has been documented in swimming sprints and multiple bicycle sprints in the older studies of Bale and Nelson (1985) and Parish and Jakeman (1987). At the end, no changes in anaerobic performance during the high jump due to the menstrual phases were found in a study with volleyball players (Ön, Diker, \& Özkamci, 2014). Tsampoukos, Packham, James, and Nevill (2010) investigated the effect of the ovulation, follicular and luteal phase on sprint performance $(2 \times 30$ seconds with $2 \mathrm{~min}$ of break). No significant changes in performance occurred during any of the three phases, even though the hormones $17 \beta$-estradiol and progesterone fluctuated significantly. Finally, Giacomoni, Bernard, Gavarry, Altare, and Falgairette (2000) did not find any significant difference in the performance (bicycle ergometer sprints, test of five repeated jumps and test of high jump) of women taking oral contraceptives and the control group during the luteal and follicular phases.

Most of these studies used one of the following methods to confirm the menstrual phase: a) counting the days since the first day of the last menstrual period, b) basal body temperature method, c) or hormonal confirmation. The latter method is the most reliable, but also the most costly. Absence of control for anxiety and depression symptoms may affect women's 
performance on anaerobic tests, hindering a consistent comparative analysis across studies (Souza, Ramos, Hara, Stumpf, \& Rocha, 2012).

Most of the studies mentioned above did not confirm any effect of the different phases of the menstrual cycle on anaerobic performance. In our work, we tried to support these investigations and bring new findings from the field of judo and menstrual cycle as well. Based on the research of most authors we expected no significant changes in anaerobic power, anaerobic capacity, fatigue index and blood lactate in the Wingate test and in all evaluated parameters of Special judo fitness test due to different phases (luteal and follicular) of menstrual cycle.

\section{Methods}

\section{Participants}

In our research we used an intentional consecutive design, where subjects performed the Wingate Test and the Special judo fitness test in their luteal and follicular phase. The research sample was composed of 8 young female judokas (age $18.14 \pm 3.44$ years; body weight $63.86 \pm 10.42 \mathrm{~kg}$; height $165.43 \pm 5.09 \mathrm{~cm}$; judo practice $11.14 \pm 3.13$ years). The main criteria to participate in this study were that all subjects were eumenorrheic and have never used oral contraceptives. Subjects were non-smokers and were not on any medications that could interfere with the experimental procedures. Their cycle length varied between 25 and 28 days. A cycle was calculated from the first day of menstrual bleeding (included) until the first day of the next bleeding (excluded).

\section{Procedure}

The young females underwent testing in $6^{\text {th }}-10^{\text {th }}$ day in the follicular phase and in $20^{\text {th }}-24^{\text {th }}$ day of luteal phase. The same research design was used by authors Middelton and Wenger (2006). The local ethics committee approved the study and it was performed according to the Declaration of Helsinki. Since part of the research sample were minors, written consent from legal representatives was required. The women informed us about their course of menstrual cycle and this information was used for test planning.

We used two anaerobic tests for our research; one of them was performed under the laboratory conditions (Wingate test for upper limbs) and the second one under the specific training conditions (Special judo fitness test). The Wingate test of upper limbs (WT) was performed in the morning at 9:00 a. m. and the Special judo fitness test (SJFT) at 7:00 p. m. To avoid the training effect, four randomly selected girls underwent an initial testing in the follicular phase and four girls in the luteal phase.

Many studies use the Wingate test for upper limbs to evaluate the anaerobic abilities of judokas (Franchini, Takito, \& Bertuzzi, 2005; Hesari, Mirzaei, Ortakand, Rabienejad, \& Nikolaidis, 2014; Obmiński, Ładyga, Borkowski, \& Wiśniewska, 2013). The reason why the WT is used is due to the fact that most of the judo moves and techniques require constant labour of the arms (e.g. to establish the grip, to prepare the attacks, to execute the throwing techniques, or to block the opponents attack). The WT for lower limbs is not used often in judo (Štefanovský, 2015). Our WT was performed on the isokinetic crank ergometer TECHNOGYM EXCITE (TECHNOGYM, Cesena, Italy) in laboratory conditions at the Slovak National Sport Center. WT is an valid and reliable technique for determining anaerobic capabilities as well as the maximal rate of fatigueless work $(r=.94)$ (Nebelsick-Gullett, Housh, Johnson, \& Bauge, 1988). Constant resistance of our apparatus is determined by the manufacturer at $2 \mathrm{~W} \cdot \mathrm{kg}^{-1}$. The women completed a five-minute warmup with the spinning speed at $60-90 \mathrm{~W} \cdot \mathrm{kg}^{-1}$ frequency (last minute spinning in opposite direction) and immediately after that executed 30 seconds WT with maximum effort. The test parameters were as follows: a) anaerobic peak power (P $\max )$; b) anaerobic capacity (P mean); c) fatigue index which expresses \% decrease in performance from the start until the end of the test; d) blood lactate in the $5^{\text {th }}$ minute after completing the test.

To evaluate the anaerobic abilities of our female judokas under specific conditions, we used Special judo fitness test, which consists of running and throws using of ippon-seoi-nage technique. The SJFT showed reliability with a low measurement error, applicability and sensitivity in training monitoring (Franchini, Nakamura, Takito, Kiss, \& Sterkowicz, 1999), in addition to high correlations compared to well-controlled laboratory tests (Franchini, Nakamura, Takito, Kiss, \& Sterkowicz, 1998; Sterkowicz, Żuchowicz, \& Kubica, 1999). It also highly correlates to number of attacks during a judo match (Franchini et al., 2005). This test has intermittent character and it is divided into three periods (15 s, $30 \mathrm{~s}$ and $30 \mathrm{~s}$ ) with 10 seconds of rest between each period. During each one of the periods the performer (TORI) throws the partners (UKE1 and UKE2), two judokas of similar stature and body mass, positioned at $6 \mathrm{~m}$ of distance one from another, using the ippon-seoi-nage technique as much as possible. At the end of the test, and 1 minute after completing the test, the heart rate of TORI was measured with POLAR RS800CX G3 (Polar Electro, Oulu, Finland). Subsequently from the number of throws and heart rate 
values is SJFT index calculated, where the lower index indicates better performance:

Heart rate after the test

SJFT index $=\frac{+ \text { Heart rate } 1 \text { min after the end of the test }}{\text { Total number of throws }}$

The test parameters were as follows: a) number of throws in the first, b) second, c) third period, d) total number of throws for all periods together and e) SJFT index. Before the beginning of SJFT all tested persons performed the classical judo warm-up and stretching, which consisted of 5 min jogging around the tatami with low intensity, $10 \mathrm{~min}$ of dynamic stretching, $10 \mathrm{~min}$ of uchi-komi and nage-komi with moderate intensity.

\section{Statistical analyses}

For the processing and evaluation of obtained data we used the basic statistical characteristics (mean and standard deviation), comparative analysis - nonparametric Wilcoxon test. Alpha was set at .05. Effect sizes are described by Cohen's $d$, whereby $0.2-0.5$ is a small, $0.5-0.8$ is a moderate, and $>0.8$ is a large effect. All descriptive statistics and difference testing was performed using IBM SPSS (Version 20 for Windows; IBM, Armonk, NY, USA).

\section{Results}

\section{Wingate test}

The anaerobic peak power ( $\mathrm{P} \max$ ) of our research sample in the Wingate test was during a LP 7.11 $( \pm 1.03) \mathrm{W} \cdot \mathrm{kg}^{-1}$ and was comparable to FP 6.48 $( \pm 1.15) \mathrm{W} \cdot \mathrm{kg}^{-1}$. We found no significant differences between $\mathrm{P}$ max in both phases $(p=.11$; Cohen's $d=0.578)$. Almost identical values of anaerobic capacity (P mean) in LP and FP were found in the same test (LP: $4.75 \pm 1.03 \mathrm{~W} \cdot \mathrm{kg}^{-1}$; FP: $4.71 \pm 0.91 \mathrm{~W} \cdot \mathrm{kg}^{-1}$; $p=.85$; Cohen's $d=0.041$ ).

The fatigue index in LP was $56.71( \pm 11.44) \%$ and it is $9 \%$ higher than in FP $47.86( \pm 10.06) \%$. Despite of this fact no significant difference was found $(p=.21$; Cohen's $d=0.823$ ).

The blood lactate in $5^{\text {th }}$ min after completing the test was comparable in both phases (LP: $9.88 \pm 1.77 \mathrm{mmol} \cdot \mathrm{l}^{-1}$; FP: $10.91 \pm 2.77 \mathrm{mmol} \cdot 1^{-1} ; p=.28$; Cohen’s $d=0.454$ ).

\section{Special judo fitness test}

The mean values for the number of throws in SJFT were in the LP: $1^{\text {st }}$ period $5.88( \pm 0.353)$ throws; $2^{\text {nd }}$ period $10.25( \pm 0.46)$ throws; $3^{\text {rd }}$ period $9.5( \pm 0.53)$ throws; all periods together $25.63( \pm 0.74)$ throws. In the FP the research sample reached the following values: $1^{\text {st }}$ period $5.38( \pm 0.52)$ throws; $2^{\text {nd }}$ period 10 $( \pm 0.53)$ throws; $3^{\text {rd }}$ period $9.5( \pm 0.53)$ throws; all periods together $24.88( \pm 0.99)$ throws. We found out significant differences of performance only in the first 15 -s period in behalf of luteal phase $(p=.03)$. Cohen's $d$ was 1.149 , which can be considered as a large effect (Figure 1). The second ( $p=.45$; Cohen's $d=0.505$ ) and third $(p=.73$; Cohen's $d=0.229)$ period of throws and total number of throws $(p=.31$; Cohen's $d=0.646)$ as well in the SJFT remained unchanged without any influence of menstrual phases. The mean value for SJFT index in the LP was $13.73( \pm 0.5)$ and in the FP $14.04( \pm 0.79)$. No significant differences ( $p=.10$; Cohen's $d=0.481$ ) have been observed due to changes of menstrual phases.

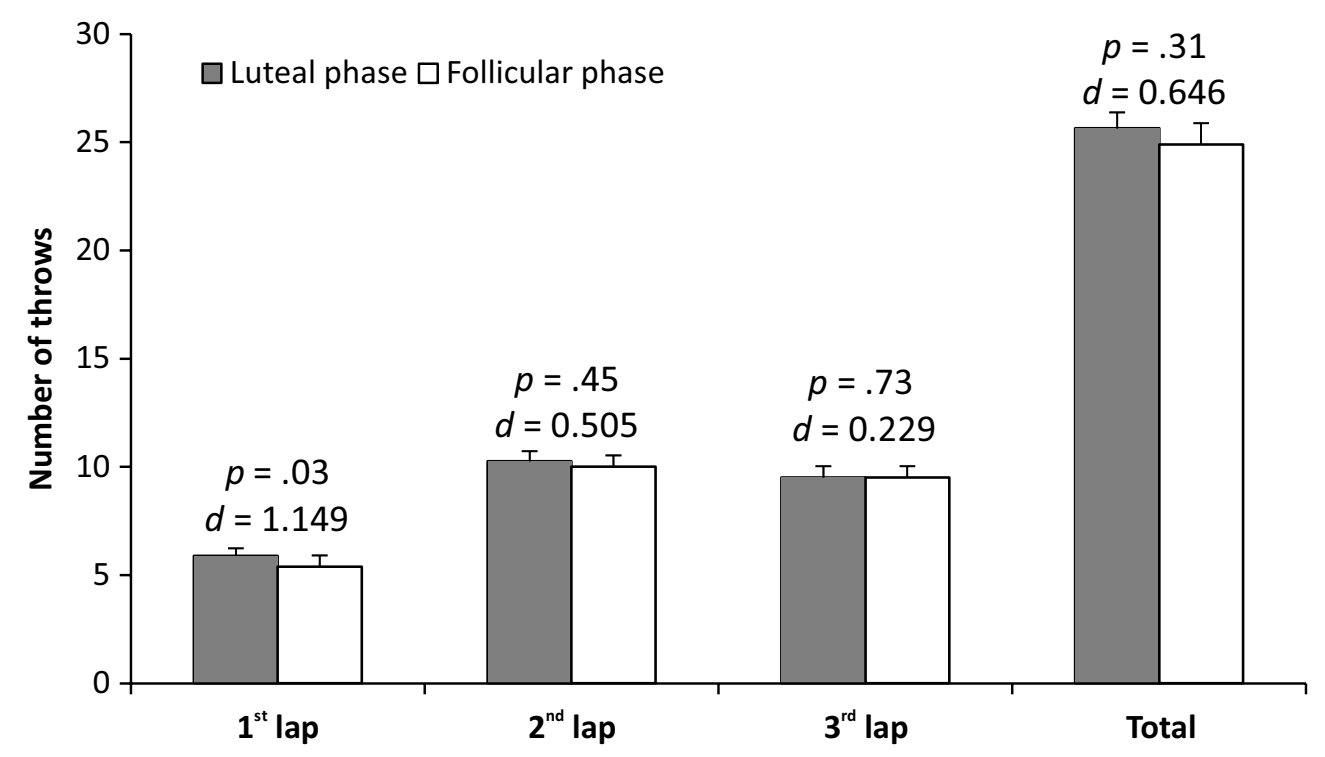

Figure 1. Mean values for number of throws in individual laps and total after performing SJFT in luteal and follicular phase of menstrual cycle. 


\section{Discussion}

In our research we found that phases of the menstrual cycle affect specific high intensity performance in the first 15-s lap of SJFT. Studies that base menstrual cycle phase confirmation on counting days use different criteria to define the luteal and follicular phases (Souza et al., 2012). Epting and Overman (1998) as well as Phillips and Sherwin (1992) reported that all studies from this field should investigate the occurrence of anovulatory cycles, since only $62 \%$ of women in the $20-24$ age groups ovulate in all menstrual cycles. Because anovulatory cycles have been associated with absence of progesterone increases in the luteal phase, failing to detect for this data (or eliminate them from the analyses) would decrease the probability of detecting abnormalities across the menstrual cycle (Broverman et al., 1981; Souza et al., 2012). Despite this fact, better performance in the first segment of SJFT can be explained with the study of authors Nicklas, Hackney, and Sharp (1989), using biopsies of vastus lateralis muscle, found that glycogen repletion and therefore glycogen muscle content was greater during the luteal phase (LP). However, the rate of glycogen utilization during exhaustive exercise did not vary significantly between the follicular and the luteal phases of the ovarian cycle. In our study, the duration of muscle exercises in the first period of SJFT was only 15 second. In such exercises, muscle energy is supplied mainly by adenosine triphosphate (ATP) and creatine phosphate (CP). There is only little evidence about influence of the ovarian cycle phase on muscle phosphate utilization. Harber, Petersen, and Chilibeck (1998) demonstrated that amenorrheic endurance trained athletes have slower $\mathrm{CP}$ recovery rates, following plantar flexion exercises, than their eumenorrheic counterparts, suggesting an influence of ovarian hormone status on muscle phosphate recovery. Middelton and Wenger (2006) reported better total work after 10 times 6-second sprint in the cycle ergometer. These authors think that higher phosphocreatine (PCr) and adenosine triphosphate stores would explain the higher performance during LP. According to Gaitanos, Williams, Boobis, and Brooks (1993), 84\% of the anaerobic ATP production in the last of ten sprints is from phosphagen stores. Therefore, increased $\mathrm{PCr}$ and ATP stores may sustain higher ATP utilization levels and allow for more consistent work levels. Higher PCr and ATP levels have been associated with high estrogen levels in the hamster uterus as present in the LP relative to the FP but not in humans or skeletal muscles (Shivaji, Devi, Ahmad, \& Sundaram, 1995).

Our other followed parameters in Wingate test and SJFT test remained unchanged and the differences were not statistically significant. The blood lactate level is in accordance for example with authors Bonen et al. (1983) and Galliven et al. (1997). These authors did not find any significant differences after the load in different phases of menstrual cycle. De Bruyn-Prevost, Masset, and Sturbois (1984) or Lebrun, Mckenzie, Prior, and Taunton (1995) also failed to observe any significant variations in anaerobic performances during the menstrual cycle. Miskec, Potteiger, Nau, and Zebas (1997) followed 15 seconds repeated high intensity anaerobic performance of rugby players in different conditions and stages of the MC. Rectal temperature, rating of perceived exertion, blood lactate, and change in plasma volume were measured before exercise and after every 5 work/rest periods. No significant differences were observed for any of the measurements. These results indicate that individual and combined conditions of menstruation will not have an adverse effect on anaerobic power output and selected physiological responses to intermittent exercise, which is very similar to our SJFT. A recent study also did not confirm the impact of MC phases on 40 yards sprint, which is anaerobic performance as well, mostly alactic (Somoboonwong, Chutimakul, \& Sanguanrungsirikul, 2015). The purpose of their study was to examine the rise in core body temperature and the sprint performance after a 15-minute warm-up in a hot-humid environment using female soccer players during the different phases of their menstrual cycle. There were no significant differences in any parameters assessed after warm-up between the 2 phases. Finally, Belanger, Burt, Callaghan, Clifton, and Gleberzon (2013) reported better tolerance of repeated performance, improved recovery of ATP, increases tension in ligaments and tendons, what means better opportunity to use elastic energy in the FP. However, this knowledge did not have any effect on performance in our Wingate test and SJFT test.

Our results conflict with those of Parish and Jakeman (1987), who used a modified version of the Wingate anaerobic test. These authors observed maximum peak and mean power output in the follicular phase. As emphasized by Reilly and Down (1992), the Wingate and "anaerobic endurance" tests require a high motivational level and that can also affect the results in the tests.

There is no consensus in the literature on the relationship between phases of menstruation cycle and anaerobic performance. Even when positive results were reported, they were either not replicated or inconsistent. From our point of view, to determine the phases of MC it is necessary to clearly monitor the level of hormonal changes. When the method of counting of days is used, results can be unstable and hardly repeatable. The poor understanding currently available of the effects of other neurobiological substances on performance, as well as the influence of environmental variables (e.g. 
stress, sleep deprivation, diet), should be taken into consideration (Sherwin, 2003; Souza et al., 2012).

However, the findings of our study must be interpreted with caution, because of a small research sample and absence of knowledge of type and level of hormones.

\section{Conclusions}

A higher number of throws in the first 15-s lap of the Judo Fitness Test with better performance in luteal phase can be a result of potential higher phosphocreatine and adenosine triphosphate stores, which can have a positive effect on higher anaerobic performance in luteal phase.

Further investigation of the menstrual cycle phases and their impact should be aimed to monitor anaerobic performance at the beginning of menstruation in women suffering from pre-menstrual syndrome, or during a rapid body weight loss.

\section{Acknowledgment}

This study was supported by a Scientific Grant Agency of the Ministry of Education of Slovak Republic VEGA No. $1 / 0556 / 14$.

\section{Conflict of interest}

There were no conflicts of interest.

\section{References}

Bale, P., \& Nelson, G. (1985). The effects of menstruation on performance of swimmers. Australian Journal of Science and Medicine in Sport, 17, 19-22.

Bangsbo, J., \& Reilly, T. (1998). Anaerobic and aerobic training. In B. Elliot (Ed.), Training in sport. Applying sport science (pp. 351-409). Chichester, United Kingdom: John Wiley \& Sons.

Belanger, L., Burt, D., Callaghan, J., Clifton, S., \& Gleberzon, B. J. (2013). Anterior cruciate ligament laxity related to the menstrual cycle: An updated systematic review of the literature. Journal of the Canadian Chiropractic Association, 57, 76-86.

Bonen, A., Haynes, F. J., Watson-Wright, W., Sopper, M. M., Pierce, G. N., Low, M. P., \& Graham, T. E. (1983). Effects of menstrual cycle on metabolic responses to exercise. Journal of Applied Physiology, 55, 1506-1513.

Broverman, D. M., Vogel, W., Klaiber, E. L., Majcher, D., Shea, D., \& Paul, V. (1981). Changes in cognitive task performance across the menstrual cycle. Journal of Comparative and Physiological Psychology, 95, 646-654.
Burrows, M., \& Bird, S. R. (2005). Velocity at $\mathrm{VO}_{2} \max$ and peak treadmill velocity are not influenced within or across the phases of the menstrual cycle. European Journal of Applied Physiology, 93, 575-580.

Callister, R., Callister, R. J., Staron, R. S., Fleck, S. J., Tesch, P., \& Dudley, G. A. (1991). Physiological characteristics of elite judo athletes. International Journal of Sports Medicine, 12, 196-203.

De Bruyn-Prevost, P., Masset, C., \& Sturbois, X. (1984). Physiological response from 18-25 years women to aerobic and anaerobic physical fitness tests at different periods during the menstrual cycle. Journal of Sports Medicine, 24, 144-148.

Epting, L. K., \& Overman, W. H. (1998). Sex-sensitive tasks in men and women: A search for performance fluctuations across the menstrual cycle. Behavioral Neuroscience, 112, 1304-1317.

Franchini, E., Nakamura, F. Y., Takito, M. Y., Kiss, M. A., \& Sterkowicz, S. (1998). Specific fitness test developed in Brazilian judoists. Biology of Sport, 15, 165-170.

Franchini, E., Nakamura, F. Y., Takito, M. Y., Kiss, M. A., \& Sterkowicz, S. (1999). Análise de um teste específico para o judô [Analysis of special test in judo]. Revista Kinesis, 21, 91-108.

Franchini, E., Takito, M. Y., \& Bertuzzi, R. C. M. (2005). Morphological, physiological and technical variables in high-level college judoists. Archives of Budo, 1, 1-7.

Gaitanos, G. C., Williams, L., Boobis, L. H., \& Brooks, S. (1993). Human muscle metabolism during intermittent maximal exercise. Journal of Applied Physiology, 75, 712-719.

Galliven, E. A., Singh, A., Michelson, D., Bina, S., Gold, P. W., \& Deuster, P. A. (1997). Hormonal and metabolic responses to exercise across time of day and menstrual cycle phase. Journal of Applied Physiology, 83, 1822-1831.

Ganong, W. F. (2005). Přehled lékařské fyziologie [Overview of Medical Physiology] (20th ed.). Prague, Czech Republic: Galén.

Giacomoni, M., Bernard, T., Gavarry, O., Altare, S., \& Falgairette, G. (2000). Influence of the menstrual cycle phase and menstrual symptoms on maximal anaerobic performance. Medicine \& Science in Sports \& Exercise, 32, 486-492.

Glaister, M. (2005). Multiple sprint work: Physiological responses, mechanisms of fatigue and the influence of aerobic fitness. Journal of Sports Medicine, 35, 757-777.

Harber, V. J., Petersen, S. R., \& Chilibeck, P. D. (1998). Thyroid hormone concentrations and muscle metabolism in amenorrheic and eumenorrheic athletes. Canadian Journal of Applied Physiology, 23, 293-306.

Hesari, F. A., Mirzaei, B., Ortakand, M. S., Rabienejad, A., \& Nikolaidis, T. P. (2014). Relationship between aerobic and anaerobic power, and Special Judo Fitness Test (SJFT) in elite Iranian male judokas. Apunts. Medicina de l'Esport, 49(181), 25-29.

Klump, K. L., Keel, P. K., Racine, S. E., Burt, S. A., Burt, S. S., Neale, M., ... Hu, J. Y. (2013). The interactive effects of estrogen and progesterone on changes in emotional eating across the menstrual cycle. Journal of Abnormal Psychology, 122, 131-137.

Lamina, S., Hanif, S., \& Muhammed, H. (2011). Influence of menstrual cycle on maximal aerobic power of young female adults. African Journal of Physiotherapy and Rehabilitation Sciences, 3, 36-41. 
Lebrun, C. M., McKenzie, D. C., Prior, J. C., \& Taunton, J. E. (1995). Effects of menstrual cycle phase on athletic performance. Medicine \& Science in Sports \& Exercise, 27, 437-444.

Losos, J. B., Raven, P. H., Johnson, G. B., \& Singer, S. R. (2002). Biology. New York, NY: McGraw-Hill.

Máček, M., \& Radvanský, J. (2011). Fyziologie a klinické aspekty pohybové aktivity [Physiology and clinical aspects of physical activity]. Prague, Czech Republic: Galén.

Masterson, G. (1999). The impact of menstrual phases on anaerobic power performance in collegiate women. Journal of Strength and Conditioning Research, 13, 325-329.

McMahon, S., \& Jenkins, D. (2002). Factors affecting the rate of phosphocreatine resynthesis following intense exercise. Journal of Sports Medicine, 32, 761-784.

Middelton, L. E., \& Wenger, H. A. (2006). Effects of menstrual phase on performance and recovery in intense intermittent activity. European Journal of Applied Physiology, 96, 53-58.

Miskec, C. M., Potteiger, J. A., Nau, K. L., \& Zebas, C. J. (1997). Do varying environmental and menstrual cycle conditions affect anaerobic power output in female athletes? Journal of Strength and Conditioning Research, 11, 211-288.

Muramatsu, S., Horiyasu, T., Sato, S. I., Hattori, Y., Yanagisawa, H., \& Onozawa, K. (1994). The relationship between aerobic capacity and peak power during intermittent anaerobic exercise of judo athletes. Bulletin of the Association for the Scientific Study on Judo Kodokan, 8, 151-160.

Nebelsick-Gullett, L. J., Housh, T. J., Johnson, G. O., \& Bauge, S. M. (1988). A comparison between methods of measuring anaerobic work capacity. Ergonomics, 31, 1413-1419.

Nicklas, B. J., Hackney, A. C., \& Sharp R. L. (1989). The menstrual cycle and exercise: Performance, muscle, glycogen, and substrate responses. International Journal of Sports Medicine, 10, 264-269.

Obmiński, Z., Ładyga, M., Borkowski, L., \& Wiśniewska, K. (2013). The effect on 4-month judo training period on anaerobic capacity, blood lactate changes during the post Wingate test recovery, and resting plasma cortisol, and testosterone levels in male senior judokas. Journal of Combat Sports and Martial Arts, 4, 119-123.

Ön, S., Diker, G., \& Özkamçi, H. (2014). Effect of menstrual cycle, anaerobic power and active jumping performance at adolescent volleyball athletes. E-Journal of New World Sciences Academy, 9(2), 32-42.

Oosthuyse, T., Bosch, A. N., \& Jackson, S. (2005). Cycling time trial performance during different phases of the menstrual cycle. European Journal of Applied Physiology, 94, 268-276.

Parish, H. C., \& Jakeman, P. M. (1987). The effects of menstruation upon repeated maximal sprint performance. Journal of Sports Science and Medicine, 1, 78.

Phillips, S. M., \& Sherwin, B. B. (1992). Variations in memory function and sex steroid hormones across the menstrual cycle. Psychoneuroendocrinology, 17, 497-506.

Pulkkinen, W. J. (2001). The sport science of elite judo athletes. Guelph, Canada: Pullkinetics.

Reilly, T., \& Down, A. (1992). Investigation of circadian rhythms in anaerobic power and capacity of the legs. Journal of Sports Medicine and Physical Fitness, 32, 343-347.

Sherwin, B. B. (2003). Estrogen and cognitive functioning in women. Endocrine Reviews, 24, 133-151.
Sherwood, L. (2013). Human physiology: From cells to systems (8th ed.). Belmont, CA: Cengage.

Shivaji, S., Devi, L. G., Ahmad, M. B., \& Sundaram, C. S. (1995). 31P NMR study of phosphorus containing metabolites in the uterus of hamster: changes during the estrous cycle and the effect of hormonal manipulation. Journal of Steroid Biochemistry and Molecular Biology, 52, 587-594.

Silverthorn, D. U. (2013). Human physiology: An integrated approach (6th ed.). Glenview, IL: Pearson Education.

Somboonwong, J., Chutimakul, L., \& Sanguanrungsirikul, S. (2015). Core temperature changes and sprint performance of elite female soccer players after a 15-minute warm-up in a hot-humid environment. Journal of Strength and Conditioning Research, 29, 262-269.

Souza, E. G. V., Ramos, M. G., Hara, C., Stumpf, B. P., \& Rocha, F. L. (2012). Neuropsychological performance and menstrual cycle: A literature review. Trends in Psychiatry and Psychotherapy, 34, 5-12.

Sterkowicz, S., Żuchowicz, A., \& Kubica, R. (1999). Levels of anaerobic and aerobic capacity indices and results for the special fitness test in judo competitors. Journal of Human Kinetics, 2, 115-132.

Štefanovský, M. (2008). Hierarchia motorických faktorov v štruktúre športového výkonu $v$ džude dorastencov [Hierarchy of motor factors in the sport performance in cadet's judo]. Bratislava, Slovakia: Comenius University in Bratislava.

Štefanovský, M. (2015). Fyziologické, motorické a somatické charakteristiky džudistov z hladiska veku a úrovne trénovanosti [Physiological, motoric and somatic characteristics of judokas according to age and training status]. Bratislava, Slovakia: Slovak Scientific Society for Physical Education and Sport.

Štefanovský, M., Laczo, E., Kraček, S., Csáderová, Z., Lopata, P., \& Lengvarský, L. (2014). Lactate metabolism in dependence on the level of aerobic abilities of judokas. Acta Facultatis Educationis Physicae Univeritatis Comenianae, 54(2), 5-10.

Tabata, I., Irisawa, K., \& Kouzaki, M. (1997). Metabolic profile of high intensity intermittent exercises. Medicine \& Science in Sports \& Exercise, 29, 390-395.

Takahashi, R. (1992). Power training for judo. Plyometric training with medicine balls. National Strength and Conditioning Association Journal, 14, 66-71.

Thomas, S. G., Cox, M. H., LeGal, Y. M., Verde, T. J., \& Smith, H. K (1989). Physiological profiles of the Canadian national judo team. Canadian Journal of Sport Science, 14, 142-147.

Tsampoukos, A., Packham, E. A., James, R., \& Nevill, M. E. (2010). Effect of menstrual cycle phase on sprinting performance. European Journal of Applied Physiology, 109, 659-667.

Vaiksaar, S., Jürimäe, J., Mäestu, J., Purge, P., Kalytka, S., Shakhlina, L., \& Jürimäe, T. (2011). No effect of menstrual cycle phase and oral contraceptive use on endurance performance in rowers. Journal of Strength and Conditioning Research, 25, 1571-1578.

Wearing, M. P., Yuhosz, M. D., Campbell, R., \& Love, E. J. (1972). The effect of the menstrual cycle on tests of physical fitness. Journal of Sports Medicine, 12, 38-41. 